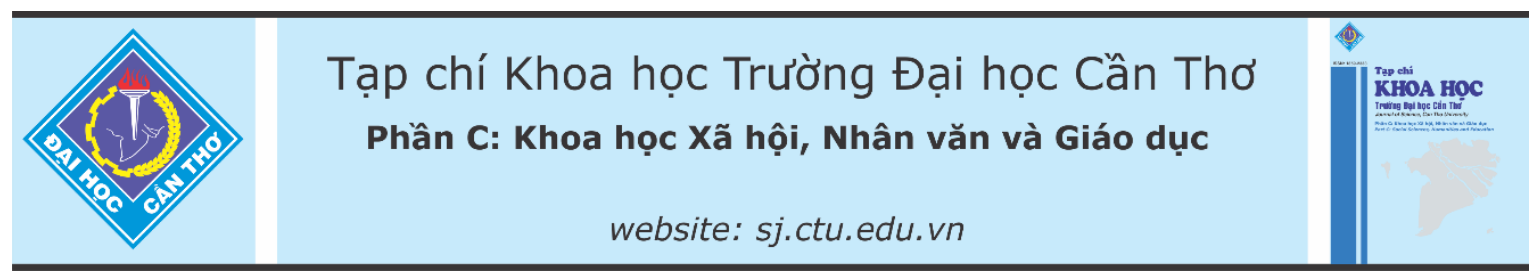

DOI:10.22144/ctu.jvn.2021.026

\title{
THƠ MỚI VIÊTT NAM TRONG BỐI CẢNH HIỆN ĐẠI HÓA THƠ CA ĐÔNG Á NỬA ĐẦU THẾ KỶ XX
}

\author{
Kiều Thanh Uyên* \\ Khoa Ngũ văn và Lịch sủ, Truờng Đại học Đà Lạt \\ *Nguời chịu trách nhiệm về bài viết: Kiều Thanh Uyên (email: uyenkt@dlu.edu.vn)
}

\section{Thông tin chung:}

Ngày nhận bài: $31 / 08 / 2020$

Ngày nhận bài sưa: $28 / 10 / 2020$

Ngày duyệt đăng: 27/02/2021

\section{Title:}

Vietnamese New Poetry Movement in the modernizing context of East Asian poetry in the first half of the twentieth century

\section{Tù khóa:}

Bối cảnh hiện đại hóa, tho ca Đông Á, Tho móri Việt Nam

\section{Keywords:}

East Asian poetry, modernizing context, Vietnamese New Poetry Moveme

\begin{abstract}
The Vietnamese New Poetry Movement is one of the outstanding achievements of the modernization of Vietnamese literature in the first half of the twentieth century. Moreover, the New Poetry movement has contributed to bringing Vietnamese literature out of regional influence and catching up with the world literature trend. This paper mainly points out and analyzes the characteristics and nature of the Vietnamese New Poetry movement from the context of modernizing East Asian poetry.
\end{abstract}

\section{TÓM TẮT}

Phong trào Tho mới là một trong nhũng thành tưu nổi bật của quá trình hiện đại hóa văn học Việt Nam nưa đầu thế kỷ XX. Hơn nũa, phong trào Tho mói còn góp phần đura văn hoc Việt Nam bước ra khỏi tầm ảnh huơơng khu vưc và bắt kịp xu thế văn học thế giới. Bài viết này chủ yểu chỉ ra và phân tích đặc điểm cũng nhu tính chất của phong trào Tho mới Việt Nam nhìn tù bối cảnh hiện đại hóa tho ca Đông Á.

\section{1. ĐẶT VẤN ĐỀ}

Không thể phủ nhận tác động của trào lưu tư tưởng phương Tây đến quá trình hiện đại hóa của văn học Việt Nam nói chung cũng như sự ra đời của phong trào Thơ mới nói riêng. Tuy nhiên, phong trào Thơ mới ra đời cũng dựa trên nhu cầu cách tân của văn học Việt Nam nửa đầu thế kỷ XX trước ngưỡng cửa mở rộng và giao lưu về mặt văn hóa trong khu vực văn hóa Đông Á. Hơn nữa, các nước Đông Á, hay còn gọi là các nước trong khu vực đồng văn, đều đã từ bỏ hệ hình văn học trung đại chịu ảnh hưởng của Trung Quốc để học tập mẫu hình văn học phương Tây.

Bên cạnh việc tiếp nhận và vận dụng mẫu hình văn học phương Tây với các trào lưu lãng mạn, tượng trưng hay siêu thực, các nhà Thơ mới Việt
Nam còn chú trọng sáng tạo và lưu giữ hồn thơ dân tộc. Điều này được minh chứng qua ba dòng chính của phong trào Thơ mới mà Hoài Thanh trong Thi nhân Việt Nam chỉ ra, gồm dòng thơ chịu ảnh hưởng thơ Đường, dòng thơ chịu ảnh hưởng phương Tây và dòng thơ Việt hóa. Có thể thấy, phong trào Thơ mới mang tính cách tân nhưng không tách rời khỏi bản sắc văn học dân tộc và văn học khu vực Đông Á. Do vậy, vấn đề phong trào Thơ mới nhìn từ bối cảnh hiện đại hóa thơ ca Đông Á nửa đầu thế kỷ XX cần được nghiên cứu xác đáng.

\footnotetext{
2. TÌNH HÌNH NGHIÊN CÚU THƠ MỚI VIÊT NAM VÀ PHONG TRÀO HIÊN ĐẠI HÓA THƠ CA ĐÔNG Á NỬ ĐẦ THẾ KỶ XX
} 
Đối với sự hình thành và phát triển của phong trào Thơ mới Việt Nam, các nhà nghiên cứu chủ yếu nhấn mạnh sự tác động của văn học phương Tây. Tuy nhiên, gần đây, các nhà nghiên cứu còn chú trọng so sánh và liên hệ giữa phong trào Thơ mới Việt Nam với các nước trong khu vực. Tức là xem phong trào Thơ mới Việt Nam không chỉ là sản phẩm của nhu cầu đổi mới tự thân và hệ quả của quá trình tiếp xúc văn hóa phương Tây mà còn là kết quả của quá trình giao lưu văn học trong bối cảnh khu vực. Do đó, có khá nhiều công trình cũng như hội thảo quốc tế được tổ chức xoay quanh vấn đề này. Một số bài nghiên cứu tiêu biểu theo hướng nghiên cứu này như Tho mói - Một hiện tuoơng lịch sủ có tính khu vục (Phan Trọng Thưởng, 2012), Con đường hiện đại hóa văn học của các nuớc khu vục văn hóa chũ Hán (Qua tu liệu văn học Việt Nam và Nhật Bản) (Đoàn Lê Giang, 2011), Cuộc gặp gõ Đông Tây và co duyên tiến bộ của văn học các nước Đông Á (Qua thực tiễn văn học Trung Quốc và Việt Nam) (Trần Đình Sử, 2011), Hiện đại hóa văn học đầu thế kỷ XX, Nghiên cưu so sánh trường hợ Hàn Quốc và Việt Nam (Nguyễn Thị Thanh Xuân, 2011), Văn hoc Việt Nam và hành trình giao luu văn hóa khu vưc và quốc tế (Đặng Thanh Lê, 2006),... Đây là những nghiên cứu mang tính định hướng mới về phong trào Thơ mới Việt Nam. Qua đó có thể thấy, nghiên cứu về Thơ mới đã có cái nhìn đa chiều, đa diện hơn.

Ở Việt Nam, nghiên cứu về văn học Đông Á chủ yếu là những nghiên cứu về các nền văn học riêng lẻ như Trung Quốc, Nhật Bản hay Hàn Quốc. Trong đó, những công trình dày dặn và công phu về các nền văn học Đông Á như Vắn học Trung Quốc hiện đại $(1898$ - 1960) (Nguyễn Hiến Lê, 1993), Tổng quan lịch sủ văn hoc Nhật Bản (Nguyễn Nam Trân, 2001), Nhà văn Nhật Bản thế kỷ XX (Đào Thị Thu Hằng, 2018),... Ngoài ra còn các các bài nghiên cứu về văn học các nước Đông Á như Yếu tố nội sinh và ngoại sinh trong sự hình thành, phát triển "văn hoc mói" (Sin Munhak) Korea tù nhũng phối cảnh nghiên cúu (Phan Thu Hiền, 2011), Phong cách tho Ngải Thanh và nhũng ảnh hường tù̀ phái tương trung (Lê Quang Trường, 2011), Quá trình hiện đại hóa văn học Trung Quốc cuối thể kỷ XIX - đầu thế kỷ XX: Sư tuoong tác giũa nhũng chuyển biến tư thân với các ảnh hưởng tù̀ thế giới bên ngoài (Phan Thu Vân, 2011), Một số ảnh hương của nghệ thuật phuoong Tây hiện đại trong sáng tác của Yasunari Kawabata (Hà Văn Lưỡng, 2011),...

Cho đến nay, có khá nhiều hội thảo khoa học cũng như công trình nghiên cứu về khu vực văn học Đông Á. Có thể kể đến, Hội thảo Khoa học Quốc tế
Văn học Việt Nam trong bối cảnh giao lưu văn hóa khu vưc và quốc tế do Viện Văn học và Viện Haward Yenching tổ chức vào ngày $03-04 / 11 / 2006$ tại Hà Nội với sự tham gia của gần 200 nhà khoa học Việt Nam, Trung Quốc, Hoa Kỳ, Nga, Hàn Quốc, Đài Loan,... với 86 tham luận báo cáo. Với Hội thảo này, văn học Việt Nam được xem xét trong một bối cảnh rộng gắn với xu thế giao lưu và hội nhập đang diễn ra trên thế giới. Về một mặt nào đó, những vấn đề đặt ra ở Hội thảo này cũng có thể đồng thời được đặt ra trong thực tiễn phát triển ở nhiều nền văn học thuộc nhiều quốc gia khác nhau. Hội thảo đã hướng tới những lý giải khoa học về thực tiễn văn học như là hệ quả của giao lưu và hội nhập trong bối cảnh khu vực.

Tiếp theo, Hội thảo Quốc tế Quá trình hiện đại hóa văn học Nhật Bản và các nước khu vực văn hóa chữ Hán: Việt Nam, Trung Quốc, Hàn Quốc (từ cuối thế kỷ XIX đến đầu thế kỷ XX), được tổ chức vào tháng 3/2010 của Trường Đại học Khoa học Xã hội và Nhân văn Thành phố Hồ Chí Minh. Hội thảo đã thu hút hơn 100 tham luận của các nhà nghiên cứu ở cả trong và ngoài nước, đặc biệt là từ các trường đại học, viện nghiên cứu của Nhật Bản, Hoa Kỳ, Liên Bang Nga, Trung Quốc. Các tham luận chủ yếu trình bày về quá trình hiện đại hóa ở các nước Đông Á, so sánh các điểm tương đồng và khác biệt cũng như giới thiệu một số tác giả tiêu biểu trong quá trình hiện đại hóa ở mỗi nước.

Đến năm 2014, Trường Đại học Khoa học Xã hội và Nhân văn - Đại học Quốc gia Thành phố Hồ Chí Minh phối hợp cùng Đại học Quốc gia Seoul (Seoul National University) tổ chức Hội thảo Khoa học Quốc tế Văn học Hàn Quốc trong bối cảnh châu $A$ (Korean literature in Asian perspective) với sự tài trợ của Viện Nghiên cứu Trung ương Hàn Quốc (Academy of Korean Studies). Hội thảo này đã nhận được nhiều tham luận của các nhà khoa học từ nhiều quốc gia như Việt Nam, Hàn Quốc, Thái Lan, Trung Quốc và Nhật Bản. Đây là hội thảo nằm trong khuôn khổ của đề án Phát triển Tài nguyên Nghiên cứu và Giảng dạy văn học Hàn Quốc ở Việt Nam.

Kế tiếp là công trình Văn học Việt Nam và Nhật Bản trong bối cảnh Đông $A$ do Đoàn Lê Giang, Nhật Chiêu và Trần Thị Phương Phương tuyển chọn, giới thiệu được nhà xuất bản Văn hóa - Văn nghệ in năm 2017. Cuốn sách là khối tư liệu đồ sộ về bối cảnh giao lưu văn học Đông Á thông qua hai nền văn học Nhật Bản và Việt Nam. Được chia làm hai phần văn học Đông Á cổ điển và hiện đại, những bài viết trong công trình này đã tóm lược những vấn đề trọng tâm. Đó là cung cấp kiến thức về bối cảnh giao lưu văn 
học Đông Á, đánh giá những hiện tượng văn học tiêu biểu, so sánh và liên hệ giữa các nền văn học với phương pháp tiếp cận hiện đại. Công trình này có đóng góp rất lớn cho việc nghiên cứu khu vực văn học Đông Á.

Những Hội thảo và công trình nghiên cứu kể trên đã cung cấp nhiều kiến thức cũng như tư liệu về văn học khu vực văn học Đông Á ở nhiều phương diện như lịch sử hình thành phong trào hiện đại hóa văn học, bối cảnh giao lưu văn học khu vực hay so sánh và chỉ ra nét tương đồng giữa nền văn học các nước. Hơn nữa, những công trình kể trên còn mang tính định hướng và mở ra nhiều hướng nghiên cứu mới xoay quanh vấn đề hiện đại hóa Việt Nam trong bối cảnh giao lưu văn học khu vực ở quá khứ cũng như hiện nay.

\section{PHONG TRÀO HIÊN ĐAI HÓA THO CA ĐÔNG Á NỬA ĐÂU THẾ KỶ XX}

Phong trào hiện đại hóa thơ ca vào nửa đầu thế kỷ XX không phải là hiện tượng văn học riêng lẻ mang tính cục bộ mà là trào lưu mang tính chất khu vực và lần lượt xuất hiện ở hầu hết các nước Đông Á vào những năm từ cuối thế kỷ XIX đến đầu thế kỷ XX. Mặc dù có sự chênh nhau đôi chút về mặt thời gian nhưng các nước trong khu vực văn học chữ Hán, hay nói cách khác là khu vực Đông Á, phong trào hiện đại hóa thơ ca đều hình thành và phát triển mạnh mẽ. Phong trào Thơ mới ở các nước Đông Á vào đầu thế kỷ $X X$ còn gánh vác sứ mệnh tiên phong cho phong trào hiện đại hóa văn học, cắt đứt với mẫu hình văn học Trung Quốc đang rơi vào tình trạng trì trệ, bế tắc. Mặt khác, phong trào Thơ mới ở các nước Đông Á không chỉ là hệ quả của con đường duy tân văn học mà còn chứng tỏ khả năng tiếp thu và sáng tạo trên cơ sở học tập các trào lưu tư tưởng phương Tây.

Hầu hết các trào lưu tư tưởng phương Tây cho đến nửa đầu thế kỷ $\mathrm{XX}$ đều được tiếp thu và tái hiện trong phong trào hiện đại hóa thơ ca ở các nước Đông Á. Từ trào lưu lãng mạn của 400 năm trước cho đến những trào lưu thời thượng lúc bấy giờ như tượng trưng, siêu thực, đa đa, vị lai,... đều hiện diện trong đời sống thơ ca ở các nước Đông Á. Mặc dù mức độ tiếp nhận sâu rộng khác nhau ở mỗi nước tùy thuộc vào nội lực, lực lượng sáng tác và những điều kiện khách quan khác nhưng các nước Đông Ả đều ra sức cập nhật các trào lưu tư tưởng phương Tây. Có thể thấy rõ nhất điều này trong trường hợp phong trào Thơ mới Việt Nam, chỉ trong thời gian rất ngắn nhưng cũng đã tái diễn được các trào lưu lãng mạn, tượng trưng và chớm sang siêu thực với thơ của Hàn Mặc Tử, Bích Khê,... hay như trường hợp phong trào Thơ mới ở Hàn Quốc (Chu Yo-han, Hong Say-ong,...) tiếp nhận thông qua khúc xạ ở môi trường văn học Nhật Bản nhưng cũng phát triển mạnh mẽ.

Do bối cảnh lịch sử, xã hội và văn hóa ở các nước khu vực Đông Á bắt đầu có sự phân hóa vào cuối thế kỷ XIX đầu thế kỷ XX, không còn chịu sự chi phối của Nho giáo hay mẫu hình Trung Quốc, cho nên phong trào hiện đại hóa thơ ca cũng có những điểm khác biệt ở mặt đề tài, thể loại. Tuy nhiên, điểm chung bao trùm bầu sinh quyển của phong trào Thơ mới ở các nước Đông Á là khát vọng khẳng định vị trí của "Cái Tôi cá nhân", vốn bị kiềm tỏa bởi môi trường văn học trung đại.

Nếu xét về mặt niên biểu, có thể thấy, phong trào Thơ mới ở Việt Nam hình thành có phần chậm trễ hơn các nước trong khu vực như Nhật Bản (1882), Trung Quốc (1921), Triều Tiên (1926), Việt Nam (1932). Điều này có thể được giải thích như sau, ở trường hợp Nhật Bản là đất nước sớm mở cửa và tiếp xúc với văn hóa phương Tây. Hơn nữa, Nhật Bản còn được xem là nơi chuyển tiếp của các trào lưu tư tưởng phương Tây trước khi du nhập vào các nước khác trong khu vực. Do vậy, phong trào Thơ mới ở Nhật Bản sớm hình thành và phát triển mạnh mẽ là điều tất nhiên. Đối với Trung Quốc và Triều Tiên, gần như tương đồng về mặt thời gian, hai nước này có điểm tương đồng là đều chịu sự cai trị của Nhật Bản trong khoảng đầu thế kỷ XX. Nhật Bản lúc bấy giờ được xem là trung tâm văn hóa "phương Tây” ở Á Đông. Do vậy, Trung Quốc và Triều Tiên cũng có những điều kiện thuận lợi khi tiếp thu tư tưởng, văn hóa phương Tây. Còn trường hợp Việt Nam, sau thời gian phân tranh Trịnh - Nguyễn cùng với tình trạng khủng hoảng, bế tắc của xã hội phương Đông lại chọn cách thức "bế quan tỏa cảng" và cấm các tư tưởng văn hóa từ phương Tây. Điều này cản trở không nhỏ đối với thời điểm duy tân đất nước. Có thể thấy rõ nhất qua quá trình hình thành của chữ Quốc ngữ, vốn được khai sinh từ thế kỷ XVII, XVIII những mãi đến cuối thế kỷ XIX đầu thế kỷ XX mới được sử dụng bởi chính sách "cấm đạo" của nhà Nguyễn. Nổ súng xâm chiếm bán đảo Sơn Trà (Đà Nẵng) từ năm 1858 , tuy nhiên, mãi cho đến những năm đầu thế kỷ XX, thực dân Pháp mới bình định được Việt Nam và cho tiến hành các cuộc khai khác thuộc địa. Bên cạnh những tác động tiêu cực, các cuộc khai thác thuộc địa của thực dân Pháp đã đánh động đến tinh thần dân tộc của các nhà chí sĩ, nhà Nho cách mạng. Họ thấy rằng cần phải tìm con đường duy tân để "khai dân trí, chấn dân khí" đưa đất nước thoát ra khỏi tình trạng hiện thời. Điều này đã tác động không nhỏ đến những phong trào hiện 
đại hóa văn học sau này. Có thể nói, do những điều kiện khách quan và những biến thiên của lịch sử mà phong trào Thơ mới ở Việt Nam đã khởi động chậm hơn so với các nước trong khu vực. Tuy nhiên, phong trào Thơ mới Việt Nam vẫn diễn ra sôi nổi và trở thành hiện tượng văn học độc đáo của tiến trình văn học Việt Nam và khu vực.

Con đường hiện đại hóa văn học ở các nước Đông Á có điểm chung là đều do thơ ca mở đường tiên phong. Ở Nhật Bản, đất nước đi đầu trong việc học tập và tiếp thu trào lưu tư tưởng phương Tây cũng bắt đầu hành trình hiện đại hóa văn học bằng thơ ca. Trước tiên là những bản dịch thơ của các giả tiêu biểu của phương Tây như Vallery, Mallarme, Baudelaire,... Kế tiếp là tiến tới cách tân về mặt hình thức và dần dần khai sinh phong trào Tân thể thi. Phải đến cuối thập niên 20, bài thơ Tiểu hà của Chu Tác Nhân vào ngày 24/9/1919 mới được xem là cột mốc đánh dấu của phong trào Thơ mới Trung Quốc, thoát ly hoàn toàn thể thức thơ truyền thống. Đến năm 1923, Tân Nguyệt phái ra đời đã đưa Thơ mới Trung Quốc tiến gần hơn đến độc giả trong nước cũng như chứng tỏ khả năng tiếp thu và vận dụng trào lưu tư tưởng phương Tây trong hiện đại hóa thơ ca. Còn phong trào Thơ mới ở Triều Tiên (Sinchesi - Newstyle poems) hình thành và phát triển từ khoảng 1908 - 1920.

Phong trào hiện đại hóa thơ ca các nước Đông Á xuất phát từ nhu cầu duy tân xã hội và văn học. Điểm chung của phong trào hiện đại hóa thơ ca ở các nước Đông Á đều lựa chọn tiếp thu mẫu hình văn học phương Tây với các bước là dịch, cách tân hình thức và cuối cùng là khai sinh phong trào Thơ mới phù hợp với thể trạng của nền văn học dân tộc. Edward Wadie Said (2014) trong công trình Đông phuoong luận đã phân tích về mối quan hệ giữa phương Đông và phương Tây về mặt địa lý, chính trị cũng như văn hóa. Qua đó, có thể thấy rằng, lựa chọn học tập mẫu hình phương Tây cho công cuộc duy tân xã hội và văn học của các nước Đông Á là lựa chọn phù hợp:

Phương Đông không chỉ gần gũi về địa lý với châu Âu. Phương Đông còn được coi là vùng đất với những thuộc địa lớn nhất, giàu nhất và lâu đời nhất của châu Ầu, là nguồn gốc của các nền văn minh và ngôn ngữ châu Âu, là kẻ ganh đua về văn hóa với châu Âu, và là một trong những hình ảnh sâu đậm nhất và hay được nêu đi nêu lại nhất ở châu Âu về "Kẻ khác". Hơn nữa, phương Đông đã giúp xác định châu Âu (hoặc phương Tây) như là hình ảnh, ý tưởng nhân cách và kinh nghiệm tương phản của mình. Tuy nhiên, không một chút nào của cái phương Đông này là thuần túy tưởng tượng. Phương
Đông là một bộ phận không tách rời của nền văn minh và nền văn hóa vật chất của châu Âu (Edward, 2014, tr.28).

Xét về mặt chính trị, kinh tế và xã hội, ngoài trừ Nhật Bản, các nước Đông Á còn lại đều bị biến thành nước nửa thuộc địa hoặc thuộc địa khi mà chủ nghĩa tư bản của phương Tây tiến hành chiến lược mở rộng thị trường. Hệ quả của các cuộc khai thác thuộc địa của thực dân phương Tây là việc hình thành các đô thị ở các nước Đông Á.

Một điểm chung nữa của phong trào hiện đại thơ ca Đông Á là khởi đầu với chủ nghĩa lãng mạn. Trong thơ ca, Nhật Bản được biết đến bởi sự đa dạng và sinh động với các trào lưu văn học phương Tây như chủ nghĩa lãng mạn, chủ nghĩa tượng trưng, chủ nghĩa siêu thực,... Tập thơ đầu tiên của khuynh hướng lãng mạn chủ nghĩa ở Nhật Bản là $C o ̉$ non (Wakanashu) của nhà thơ Shimazaki Toson vào năm 1897, gồm 51 bài thơ và 1 bài tựa. Tức là khoảng 100 năm sau khi chủ nghĩa lãng mạn xuất hiện ở phương Tây. Còn ở Trung Quốc, đại biểu cho thành tựu cao nhất của Thơ mới ở thời kỳ đầu chính là chủ soái thi đàn của thi phái Sáng Tạo, nhà thơ lãng mạn Quách Mạt Nhược. Với tập thơ Nũ thần gồm 56 bài thơ, chủ yếu được sáng tác vào năm 1920, Quách Mạt Nhược tập trung thể hiện tinh thần khai sáng vĩ đại của cuộc cách mạng Ngũ Tứ. Có hẳn một trường phái thơ lãng mạn ở Triều Tiên, đó nhóm Paekcho (White Tide - Sóng trắng). Tương tự Việt Nam, thơ ca lãng mạn Triều Tiên cũng tập trung chủ đề chính là ý thức cá nhân với các tác giả tiêu biểu như Park Chong-hwa, Yi Sang-hwa, Hwang Sogu,...

Khuynh hướng hiện đại hóa thơ ca tiếp theo của khu vực văn học Đông Á là trào lưu tượng trưng. Ảnh hưởng Tây phương mạnh nhất đến thơ Nhật Bản là vào năm 1905 khi xuất hiện các bản thơ Parnasse và Tượng trưng Pháp do Ueda Bin (1874) dịch. Đến cuối thập kỷ 20 của thế kỷ XX, xu thế viết thơ theo lối tượng trưng bắt đầu được các nhà thơ Trung Quốc quan tâm. Lý Kim Phát được coi là người đầu tiên có ý thức trong việc đưa phương pháp sáng tác thơ của chủ nghĩa tượng trưng Pháp vào các tác phẩm. Với ba tập thơ Vi vũ, Vi hạnh phúc nhi ca, Thực khách dĩ hung niên kế tiếp nhau ra đời, Lý Kim Phát thực sự là người có công lớn trong việc đặt nền móng thơ ca tượng trưng tại Trung Quốc. Các nhà thơ Triều Tiên thời kỳ này (Chu Yo-han, Hong Say-ong, Pak Chong-Hwa, Yi Sang-hwa,...) cũng nỗ lực kêt hợp chủ nghĩa tượng trưng Pháp với chủ nghĩa lãng mạn. Điều này cho thấy những nỗ lực trong tiếp nhận và cập nhật các trào lưu thơ ca thời thượng chủ nghĩa hiện đại của văn học Triều Tiên. 
Trong phong trào Thơ mới Triều Tiên, Chu Yo-han là người mở đầu cho thơ văn xuôi. Đây là hình thức thơ chịu ảnh hưởng của chủ nghĩa tượng trưng Pháp và Thơ mới Nhật Bản.

Nhật Bản không chỉ hiện đại hóa thơ ca mà còn quyết tâm bắt kịp các nước phương Tây, cho nên, chủ nghĩa siêu thực cũng được chào đón và tiếp nhận một cách tích cực. Tuy nhiên, Nhật Bản không chỉ vận dụng một cách bị động mà còn tạo nên một cuộc đối thoại Đông - Tây trong quá trình tiếp nhận. Theo những khảo sát và tổng hợp của nhà nghiên cứu Lê Thụy Tường Vy (2019), chủ nghĩa siêu thực đã thu hút khá đông đảo giới văn nghệ sĩ ở Nhật Bản: “Từ một trào lưu chỉ mới du nhập vào đây những năm 20 của thế kỷ trước, chỉ 10 năm sau, Nhật Bản đã có hơn 500 nghệ sĩ theo khuynh hướng siêu thực chủ nghĩa và đến đấu thế kỷ XXI là gần 3000 người ở các lĩnh vực văn chương, hội họa, điện ảnh,..." (tr. 164).

Phong trào hiện đại hóa thơ ca Trung Quốc cũng liên tục tiếp nhận và cập nhật các trào lưu tư tưởng phương Tây. Sau Lý Kim Phát, các nhà thơ thuộc giai đoạn hậu kỳ của thi phái Sáng tạo như Mục Mộc Thiên, Phùng Nãi Siêu, Vương Độc Thanh, Diêu Bồng Tử, ... bắt đầu có sự chuyển hướng trong sáng tác. Những người này đưa ra khái niệm "thuần thi" với chất duy mỹ thấm đẫm, tính nhạc cùng ve đẹp về mặt hình thức của thơ cũng được nhấn mạnh, đặc biệt là tính hàm súc. Có thể thấy, khuynh hướng này chuyển dần từ tượng trưng sang siêu thực của thơ ca Trung Quốc.

So với thơ tượng trưng, thơ siêu thực có phần chưa đậm nét do thời gian hiện đại hóa ở khu vực Đông Á khá ngắn ngủi do những điều kiện khách quan. Tuy nhiên, những dấu ấn của thơ siêu thực trong văn học Đông Á chứng tỏ sự cập nhật cũng như nỗ lực tiếp nhận những trào lưu tư tưởng mới của phương Tây. Đồng thời, điều này còn chứng tỏ sức ảnh hưởng của chủ nghĩa hiện đại đối với văn học Đông Á. Thêm nữa, chủ nghĩa tượng trưng và siêu thực là hai trào lưu thời thượng ở phương Tây lúc bấy giờ, do vậy thơ ca Đông Á không phải tái diễn lại trào lưu đã qua mà là cập nhật bắt kịp xu thế văn học phương Tây. Trong bối cảnh vừa hiện đại hóa xã hội và văn học thì đây là nỗ lực đáng ghi nhận của phong trào thơ ca Đông Á đầu thế kỷ XX. Mặt khác, chủ nghĩa tượng trưng và siêu thực, mặc dù khởi nguồn từ phương Tây nhưng lại cho những nét tương đồng với truyền thống thơ ca Đông Á. Có thể thấy, trào lưu tượng trưng và siêu thực đã được gieo trồng trên mảnh đất thơ ca với dưỡng chất phù hợp. Vì vậy, phong trào hiện đại hóa thơ ca Đông Á dù trong thời gian ngắn và với nhiều điều kiện khách quan bất lợi nhưng đã đạt được nhiều thành tựu cũng như tiệm tiến gần với xu thế văn học thế giới.

\section{THƠ MỚI VIÊT NAM TRONG BỐI CẢNH HIỆN ĐẠI HÓA THO CA ĐÔNG Á NỬA ĐẦU THẾ KỶ XX}

Sự lựa chọn mẫu hình văn học phương Tây không chỉ là do áp lực và tác động bên ngoài mà còn theo nhu cầu tự thân của văn học Việt Nam. Kể cả các nhà Nho như Phan Bội Châu, Phan Châu Trinh,... cũng đã sử dụng chữ Quốc ngữ và loại bỏ dần cách sáng tác thơ văn theo niêm luật, hệ thống tượng trưng ước lệ. Việc nền giáo dục Hán học bị bãi bỏ cũng là một trong những lý do khiến cho Việt Nam không tiếp tục lựa chọn mẫu hình văn học Trung Quốc mà trở thành "quan hệ song hành" như

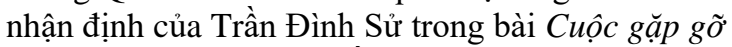
Đông Tây và co duyên tiến bộ của văn học các nước Đông Á (Qua thực tiễn văn học Trung Quốc và Việt Nam). Theo nhà nghiên cứu Đỗ Lai Thúy, cần ghi nhận sự nỗ lực của những nhà Nho tiến bộ và các trí thức Tây học trong việc dung hòa yếu tố truyền thống và ngoại lai khi hiện đại hóa văn học. Phong trào Thơ mới cũng là một trong những kết quả của những nỗ lực đó:

Nhờ sự nỗ lực của các trí thức mới như Trương Vĩnh Ký, Phan Chu Trinh, Lương Văn Can, Phạm Quỳnh, Nguyễn Văn Vĩnh,... bằng sự kết hợp Đông Tây, Việt - Pháp theo hướng hiện đại hóa, đã cho ra đời một nền văn hóa mới. Thơ mới chính là tiếng nói tinh khôi nhưng mạnh mẽ của con người cá nhân, con đẻ của nền văn hóa đô thị hiện đại này (Đỗ Lai Thúy, 2012, tr.34).

Hơn nữa, lúc này, xã hội Việt Nam đã bước vào quá trình hiện đại hóa với những đô thị mới được hình thành và tầng lớp đô thị ngày càng tăng lên về số lượng cũng như chất lượng. Do đó, yêu cầu bức thiết đặt ra cho nền văn học lúc bấy giờ không chỉ đổi mới về quan niệm, tư tưởng như Phan Bội Châu, Phan Châu Trinh hay Tản Đà mà là một cuộc cách tân từ hình thức cho đến tư tưởng. Nhà nghiên cứu Nguyễn Thanh Tâm trong Tho mới - Một diễn giải tù "Lịch sủ - Sinh thành hoc" cho rằng, phong trào Thơ mới là sản phẩm của một quá trình tích lũy lâu dài của quá trình biến đổi đất nước, con người, văn hóa và xã hội, đồng thời còn là sự dung hòa giữa yếu tố bản địa và ngoại lai:

Nền văn học mới theo hướng hiện đại hóa không phải là một sản phẩm tự nhiên mà có. Đó là kết quả của một quá trình chuyển biến lâu dài trong lòng thời đại. Sự thay đổi của đất nước, con người, văn hóa, 
phong tục Việt Nam theo hướng tích hợp với văn hóa phương Tây đã hiện hình trong văn học, văn hóa... Xét đến những biến cố của thời đại như là thành tố có tính chất nền tảng cho sự xuất hiện Thơ mới cần phải chú ý đến phong trào duy tân và những dịch chuyển trong tư tưởng của tầng lớp trí thức Việt Nam từ khi tiếp xúc và tích hợp lâu dài với nền văn hóa phương Tây trước đó (Nguyễn Thanh Tâm, 2012, tr. 103).

Phong trào Thơ mới Việt Nam không chỉ đóng vai trò cách tân hình thức thơ ca mà còn gánh vác sứ mệnh tiên phong trên con đường hiện đại hóa văn học và xã hội Việt Nam nửa đầu thế kỷ XX. Phong trào Thơ mới là sản phẩm của quá trình tiếp thu tư tưởng văn hóa phương Tây, phát huy nội lực truyền thống thơ ca trung đại và là khát vọng bày tỏ cảm xúc thành thực của thế hệ trí thức Tây học trẻ của Việt Nam nửa đầu thế kỷ XX.

Về cơ bản, tiến trình phát triển của phong trào Thơ mới Việt Nam được chia làm ba giai đoạn nếu xét ở phương diện thời gian. Từ năm 1928, bản dịch Con ve và cái kiến (La cigale, et la fourmi) của Nguyễn Văn Vĩnh từ năm 1928, đã phá vỡ vần điệu niêm luật, số câu, số chữ của thơ cũ. Đây là bản dịch thơ mang ý nghĩa đặt những viên gạch đầu tiên cho phong trào Thơ mới Việt Nam. Chặng thứ nhất từ năm 1932 đến năm 1936, đây là chặng khởi đầu đánh dấu bằng bài thơ Tình già của Phan Khôi trên báo Phụ nữ Tân văn số ra ngày 10/3/1932 với bài giới thiệu Một lối tho trình chánh giũa làng tho. Thêm nữa, ở Nam Kỳ, những bài thơ của Nguyễn Thị Manh Manh, Huỳnh Văn Nghệ, Hồ Văn Hảo,... cũng đã góp phần mở đầu cho phong trào cách tân thơ ca Việt Nam. cũng Ở chặng đường này, vẫn còn có sự đấu tranh giữa phong trào Thơ mới và Thơ cũ. Mặc dù diễn ra sự tranh luận gay gắt nhưng sự thắng thế nghiêng về phong trào Thơ mới với những tác phẩm của Thế Lữ, Vũ Đình Liên, Lưu Trọng Lư,... Tiếp theo, chặng thứ hai từ năm 1936 đến năm 1940, giai đoạn phát triển rực rỡ, diễn ra sôi nổi và đạt nhiều thành tựu của phong trào Thơ mới. Chặng đường này ghi nhận số lượng lớn tác giả, tác phẩm với sự thắng thế tuyệt đối của phong trào Thơ mới. Cho đến nay, những tác giả này vẫn là những tài năng độc đáo của thơ ca hiện đại Việt Nam như Xuân Diệu, Huy Cận, Chế Lan Viên, Hàn Mặc Tử, Bích Khê,... Cuối cùng, chặng thứ ba từ năm 1940 đến 1945, có sự phân hóa trong khuynh hướng sáng tác với những nhóm thơ như Dạ đài, Trường loạn thơ, Xuân thu nhã tập,... với những tuyên ngôn, hệ thống thi pháp, quan niệm thẩm mỹ mang màu sắc cá nhân. Tuy nhiên, các chặng đường phát triển trên đây chỉ được phân chia mang tính tiến trình của một hiện tượng văn học sử. Nhà nghiên cứu Đỗ Lai Thúy trong Tho mói thành công và thất bại của thành công đã đề xuất một tiến trình phát triển khác của phong trào Thơ mới, "Thơ mới quả thực khởi đầu với dòng thơ lãng mạn, nhưng nó không chỉ lan theo chiều ngang, tức là bành trướng cái lãng mạn ấy, mà còn phát triển theo chiều dọc, tức đi từ lãng mạn với Thế Lữ, Huy Thông, Nguyễn Bính chớm sang tượng trưng với Xuân Diệu, Huy Cận, Vũ Hoàng Chương, rồi tượng trưng với Đinh Hùng, Bích Khê, cuối cùng đặt một chân vào siêu thực với Nguyễn Xuân Sanh, Hàn Mặc Tử. Con đường đi học tuy nhỏ, nhưng là con đường của tương lai, vì nó sẽ dẫn đến sự thay đổi lớn: tức từ hiện đại/ tiền hiện đại chủ nghĩa chuyển sang thơ hiện đại chủ nghĩa (Đỗ Lai Thúy, 2012, tr.36-37).

Ở trường hợp Thơ mới Việt Nam, trào lưu lãng mạn để lại dấu ấn đậm nét hơn so với tượng trưng và siêu thực. Có thể nói, tượng trưng và siêu thực chỉ mới chớm nở trong phong trào Thơ mới Việt Nam với một vài sáng tác của Nguyễn Xuân Sanh, Đoàn Phú Tứ, Bích Khê, Hàn Mặc Tử và nhóm Dạ Đài. Phong trào Thơ mới Việt Nam cũng đã nỗ lực tiếp nhận trên cơ sở xây dựng cuộc đối thoại giữa trào lưu văn học phương Tây và truyền thống thơ ca dân tộc. Tuy nhiên, thơ tượng trưng và siêu thực ở Việt Nam chưa phát triển mạnh mẽ cũng như thu hút được giới văn nghệ sĩ như trường hợp Nhật Bản. Đây là điều đáng tiếc bởi thời gian hiện đại hóa văn học quá ngắn ngủi cùng với những điều kiện bất lợi của lịch sử. Dù vậy, những thành tựu của thơ ca tượng trưng và siêu thực của phong trào Thơ mới Việt Nam vẫn đáng trân trọng và đang được các nhà thơ thế hệ sau tiếp nối và phát triển như Vi Thùy Linh, Mai Văn Phấn,...

\section{MộT VÀI GHI NHậN}

Việt Nam là một trong bốn nước Đông Á đồng văn tiếp nhận mẫu hình văn học phương Tây trong quá trình hiện đại hóa. Văn học Việt Nam nửa đầu thế kỷ XX đã tiếp thu và vận dụng hầu hết các trào lưu tư tưởng của phương Tây thời hiện đại với nhịp độ mau lẹ. Phong trào Thơ mới là một trong những thành tựu nổi bật của quá trình hiện đại hóa văn học Việt Nam nửa đầu thế kỷ XX.

Những thành tựu này của phong trào Thơ mới, trước hết cần ghi nhận đóng góp của các nhà Nho cách mạng như Phan Bội Châu, Phan Châu Trinh đã cổ vũ việc sử dụng chữ Quốc ngữ và cách tân thơ ca về mặt hình thức. Tiếp theo, đó là lực lượng trí thức Tây học nhanh nhạy tiếp thu, học tập và sáng tạo không ngừng nghỉ trong suốt gần 15 năm của phong trào Thơ mới. Có thể nói, phong trào Thơ mới là một 
cuộc chạy tiếp sức giữa các thế hệ nhà Nho, trí thức Tây học; giữa thế hệ nhà Thơ mới đi trước với thế hệ nhà Thơ mới đi sau. Mặc dù hình thành và phát triển trong những điều kiện không thật sự thuận lợi của điều kiện khách quan nhưng phong trào Thơ mới đã diễn ra sôi nổi, phát triển mạnh mẽ. Phong trào Thơ mới trở thành một hiện tượng văn học tiêu biểu của tiến trình văn học Việt Nam hiện đại và là nền tảng vững chắc cho thơ ca sau này.

Dù trong những điều kiện không thuận lợi của bối cảnh lịch sử, chính trị nhưng văn học Việt Nam đã tận dụng những lợi thế khi tiếp thu trực tiếp văn hóa phương Tây thông qua thực dân Pháp cũng như gắn bó chặt chẽ với khu vực văn học Đông Ả. Do đó, Thơ mới Việt Nam với tư cách là phong trào cách tân thơ ca lúc bấy giờ đã nhanh chóng được hình thành và phát triển. Hơn nữa, Thơ mới Việt Nam còn cùng với thơ ca khu vực Đông Á đồng hành cùng thế giới hoàn chỉnh diện mạo một số trào lưu văn học như tượng trưng, siêu thực. Vì vậy, không thể phủ nhận vai trò của khu vực văn học Đông Á trong quá trình hình thành và phát triển phong trào Thơ mới Việt Nam. Bên cạnh tiếp nhận trực tiếp mẫu hình văn học phương Tây thông qua Pháp, văn học Việt Nam còn tiếp nhận gián tiếp cũng như những khúc xạ của nó qua môi trường văn học Đông Á. Điều này góp phần hình thành bản sắc độc đáo của phong trào Thơ mới trong môi trường văn học Việt Nam do có thể dung hòa cả tính chất hiện đại của phương Tây và truyền thống phương Đông. Có thể xem, liên hệ chặt chẽ với khu vực văn học Đông Á trong quá trình hiện đại hóa theo mẫu hình phương Tây là điểm thuận lợi của Thơ mới Việt Nam nửa đầu thế kỷ XX.

Thứ nhất, đến nửa đầu thế kỷ XX, văn học Việt Nam thoát khỏi sự chi phối của văn học Trung Quốc. Đặc biệt, phong trào Thơ mới chịu ảnh hưởng sâu sắc mẫu hình văn học phương Tây từ chủ nghĩa lãng mạn đến tượng trưng và siêu thực. Thơ mới Việt Nam cũng dần chuyển dịch từ mô hình truyền cảm sang gợi cảm, cập nhật xu hướng văn học thế giới.

Thứ hai, mặc dù, phong trào Thơ mới Việt Nam đi sau các nước trong khu vực về mặt thời gian nhưng cũng đã cập nhật hầu hết các khuynh hướng văn học phương Tây như lãng mạn, tượng trưng và siêu thực. Hơn nữa, phong trào Thơ mới cũng đạt những thành tựu đáng ghi nhận và có vị trí quan trọng tiến trình văn học Việt Nam nửa đầu thế kỷ $X X$. Có thể nói, với những thành tựu đó, phong trào Thơ mới Việt Nam cũng góp phần cùng các nước trong khu vực văn học Đông Á hiện đại hóa thi ca nửa đầu thế kỷ XX.
Thứ ba, có thể nói, Thơ mới Việt Nam có thể xem là một mảnh ghép của phong trào thơ ca Đông Á nửa đầu thế kỷ XX. Tuy nhiên, phong trào Thơ mới Việt Nam cũng là hệ quả của quá trình giao lưu khu vực, tiếp thu mẫu hình phương Tây và kết hợp nội lực truyền thống văn học dân tộc. Bằng chứng là phong trào Thơ mới Việt Nam có ba dòng thơ chính, trong đó có dòng thơ dân tộc hóa. Qua đây, có thể rút ra bài học kinh nghiệm, trong quá trình phát triển của văn học phải luôn đồng thời thực hiện hai nhiệm vụ, đó là duy trì những nét truyền thống và tiếp thu các thành tố bên ngoài để đổi mới.

Trong bối cảnh toàn cầu hóa hiện nay, văn học Việt Nam cần có nhiều sự nỗ lực hơn để tiếp cận với xu thế thế giới. Tuy nhiên, văn học Việt Nam còn cần phải quan tâm và có sự kết nối chặt chẽ với khu vực văn học Đông Á. Không chỉ là tiếp thu những tư tưởng văn nghệ mà văn học Việt Nam còn nên giao lưu, trao đổi kinh nghiệm trong sáng tác cũng như nghiên cứu văn học. Đặc biệt là hiện nay, các nước trong khu vực Đông Á như Trung Quốc, Nhật Bản, Hàn Quốc có ảnh hưởng rất mạnh mẽ đến Việt Nam thông qua văn học, điện ảnh và các loại hình văn hóa khác. Do vậy, để cập nhật xu thế văn học thế giới, văn học Việt Nam cũng cần chú trọng liên hệ chặt chẽ với văn học khu vực Đông Á. Hiện nay, văn học Việt Nam tiếp nhận nhiều khuynh hướng và trào lưu sáng tác, phê bình và nghiên cứu mới từ khu vực cũng như thế giới, chẳng hạn như thuyết nữ quyền, phê bình giới, phê bình sinh thái,... Từ những kinh nghiệm hiện đại hóa văn học nói chung và phong trào Thơ mới Việt Nam nửa đầu thế kỷ XX, văn học Việt Nam cần tận dụng trước hết là nội lực truyền thống, sau đó là phát huy học hỏi và tiếp thu kinh nghiệm từ các nước trong khu vực và thế giới.

Từ vấn đề phong trào Thơ mới Việt Nam trong mối liên hệ thơ ca Đông Á, có thể thấy, học tập cũng như tiếp nhận tư tưởng nước ngoài cần đặt trong nhiều phương diện như bối cảnh ngoại lai (tác động của tư tưởng phương Tây), nội lực truyền thống (tiềm lực văn học của mỗi quốc gia) và phối cảnh khu vực (giao lưu học hỏi qua lại giữa các nước trong khu vực).

\section{TÀI LIỆU THAM KHẢO}

Đỗ Lai Thúy (2012). Thơ mới thành công và thất bại của thành công. Nghiên cứu văn học, 6(484), 34-40.

Edward, S. W. (2014). Đông phương luận. (Lưu Đoàn Huynh, Phạm Xuân Ri, Trần Văn Tụy, \& Trần Tiễn Cao đăng dịch) Hà Nội: Tri thức.

Lê Thụy Tường Vy (2019). Bối cảnh du nhập chủ nghĩa siêu thực tại Nhật Bản. Trong Trần Thị 
Phương Phương, Huỳnh Như Phương, \& Nguyễn Ngọc Bảo Trâm (Chủ biên). Nhũng cuộc hội ngộ của văn chuoong thế giới - Văn học so sánh: Nghiên cúu và dịch thuật (trang 164-176). Nhà xuất bản Văn hóa - Văn nghệ.

Nguyễn Thanh Tâm (2012). Thơ mới - Một diễn giải từ "Lịch sử - sinh thành học". Nghiên cúu văn hoc, 6(484), 100-110.
Trần Đình Sử (2012). Mấy vấn đề thi pháp Thơ mới như là một cuộc cách mạng trong thơ Việt. Nghiên cúu Văn học, 6(484), 9-24.

Trần Đình Sử (2011).Cuộc gặp gỡ Đông Tây và cơ duyên tiến bộ của văn học các nước Đông Á (Qua thực tiển văn học Trung Quốc và Việt Nam). Trong Đoàn Lê Giang (Chủ biên). Văn hoc cận đại Đông Á tù góc nhìn so sánh (trang 28-36). Nhà xuất bản Tổng hợp Thành phố Hồ Chí Minh. 